\title{
術前に最大酸素提取量増大が求められた 肺癌患者の運動療法の経験
}

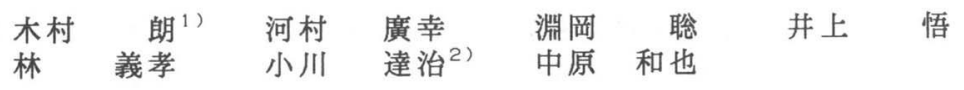

Trial of an Exercise and Physical Therapy for the Lung Cancer Patient with Lower Pulmonary Function in Pre Pulmonectomy. Akira KIMURA ${ }^{1)}$, Hi royuki KAWAMURA, Satosi FUTIOKA, Satoru InOUE, Yositaka HAYASI Tatuji OGAWA,MD2), Kazuya NAKAHARA,MD.

1) Department of Physical Therapy,Ohsaka University Hospital: 2-15 Yamadaoka Suitacity Ohsaka 565 Japan. TEL +81 6-879-5860.

J. Exerc. Physiol. 8(4):223-227,1993. Submitted Aug. 30,1993. Accepted Sep. 23,1993. ABSTRACT

This report examined the effect of the breathing training and the movement treatment based on the amount of the maximum oxygen intake before the art of the lung cancer patient to whom the generation of complications was forecast after the art.

The patient was a woman of 72 years old. The patient had the decrease of the breathing function and the trouble of the whole body endurance power. The level of the lung cancer showed an indistinct boundary and several $5.5 \times 6.0 \mathrm{~cm}$ size shadows not uniform in leaf (S9) under the left according to $X$ rays. As for the science treatment, the movement load examination and treatment of the movement of the bicycle, in which ergometer was used, repeated five minutes per 10 intervals per 50 rotations perminute of the minute four times with Watt from 25 to 54 . These exrcises was done twice during a day. Moreovur, stretching exercise of the body to improve flexibility was done and other training did the breathing resistance training by 5 minutes and PFLEX to reinforce the breathing muscle. In the result, the number of the heart beat of the average regularly became 98 at the time of beginning. Mets was 2.9. The amount of the oxygen intake was $497 \mathrm{ml} / \mathrm{minute}$ when moving highest. When the program ended, it was regular and 110 the number of the heart beat of the average. Mets was 5.2. The amount of the oxygen intake when moving highest became $891 \mathrm{ml} / \mathrm{minute}$. The value when ended became increase of $76 \%$ when beginning. This breathing training and the movement treatment have increased the amount of the oxygen intake when moving highest. The improvement of the oxygen intake shown by this program.

Key words: lung cancer, prognosis, therapeutic exercise, maximum oxygen uptake 要旨

この研究は呼吸訓練及び運動療法の効果を術後合併症の発生が予想された肺癌患者の術前に おける最大酸素摄取量をもとに調べた。患者は72歳の女性だった。患者は呼吸機能の低下と全 身持久力の障害を持っていた。肺癌の程度はレントゲンによると左下葉（S）に境界不鮮明と 大きさ $5.5 \times 6.0 \mathrm{~cm}$ の不均一の数個の陰影を示していた。理学療法は自転車エルゴメーターを使 用した運動負荷試験および、運動療法（25から54 だのWattで毎分50回転で 10 分間、インター バル5分を4回絽返した。これを1日2回行った。）を行った。また他の訓練は身体の柔軟性改善 を目的としたストレッチングを5分と、呼吸筋強化を目的としたPFLEXによる呼吸抵抗訓練を行 わせた。その結果、開始時点では定常状態の平均の心拍数は98拍になり、Mets は2.9であった。 最高運動時酸素摂取量は $497 \mathrm{ml} /$ 分であった。プログラム終了時の定常状態の平均の心拍数は 110 拍であり、Metsは5.2であった。最高運動時の酸素提取量は $891 \mathrm{~m} 1 /$ 分となり、終了時は開始時 比 $76 \%$ 増となった。この呼吸訓練及び運動療法は最高運動時の酸素摄取量を増大し、呼吸機能 の改善をもたらせた。

キ-ワード:肺癌、予後、運動療法、最大酸素摄取量

1) 大阪大学医学部附属病院理学療法部: 大阪府吹田市山田丘2-15 ( ( 565）2）同第一外科：

受付日1993年8月30日 受理日1993年9月23日 


\section{I . 緒 言}

肺癌患者で、腫演摘出術後の呼吸不全など の合併症が問題になることがある。これら術 後合併症は、外科技術における手術成績、患 者の予後、ターミナルケアを含めた Q O L に 直接関係し、リハビリテーション医療と密接 に関わっている。理学療法技術は、運動処方、 運動強度の管理技術を術前の患者に適応する ことでそれらに役立つことが期待される。関 連する研究は、三好らによると、肺癌患者に おける術後呼吸機能を残存する亜区域気管支 の数から術後合併症を予測し、予測 1 秒率が 30 $\%$ 以下の症例は有意に合併症が多かったとし ている ${ }^{1)}$ 。運動機能と予後を関連付けるもの としては、拘束性肺機能障害をもつ者の評価 には運動負荷試験時の乳酸性閥値での体表面 積あたりの酸素提取量(V02/BSA at La-2.2) が有効な指梅の1つであることを症例の群別 研究より提唱している2)。また中川らは 156 人の肺切除術を受けた肺癌患者の術後の観察 より\%FEV1が30\%より少ない場合重篤になるこ とを報告している 術後病院死の関係では Swan-Ganzカテーテル を㨂入し多段階運動負荷試験を行い,02D / BS ALa20 (Lactate $20 \mathrm{mg}$ 時点の酸素摂取量/体表 面積)で $500 \mathrm{~m} 1 / \mathrm{min} / \mathrm{m}^{2}$ が手術適応の critical pointであるとしている4)。また、三好らは肺 癌患者における術前耐運動能による術後合併 症の予測としてLa-20におけるV02/BSAが400 $\mathrm{m} l / \mathrm{m}$ in $/ \mathrm{m}^{2}$ 以下では合併症が発生すれば院内 死亡につながることを報告している゙”。

ここで、これらの知見において BSAはおよ そ体重の $1 / 1.4$ と考えられることから La20時 点が心拍数 100 時点の酸素摄取量として換算 すると $400 \mathrm{~m} 1 / \mathrm{BSA} / \mathrm{min}$ は $560 \mathrm{ml} / \mathrm{kg} / \mathrm{min}$ となり、 この値を指梅とした場合には、術前において、 最大酸素摄取量がおよそ $560 \mathrm{ml} / \mathrm{min}$ 以下の症 例では術後の呼吸不全等の発生により死に至 る確率が高いとしている。呼吸訓練及び運動
療法によって最大酸素提取量の増大が得られ れば、それらの予防が可能であると我々は考 えた。

ここでは、術前にできうる限りの最大酸素 摂取量の増大が術後の合併症発生を予防する ために求められた肺癌患者における、呼吸訓 練及び運動療法の経験と、検討すべき事項に ついて報告する。試行錯誤の中で、実験研究 的に言えば仮説に当る、本臨床研究のテーマ

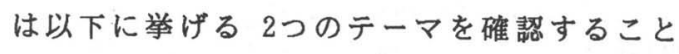
を目的に、理学療法を行った。第一は果たし て患者はこのような治療プログラムを受入れ、 運動強度設定管理が成功するか不か、第二に 最大酸素摂取量は增大寸るか。本患者におけ る治療過程と結果の記録を検討し、報告する。

\section{II. 患者情報}

年齢 : 72 歳

性別：女性

身長: $155 \mathrm{~cm}$

体重： $49 \mathrm{~kg}$

職業：無職

疾患名：肺癌

障害名: 呼吸機能低下、全身持久力障害

現症: 左下葉（S9）の境界不鮮明、大きさ5. $5 \times 6.0 \mathrm{~cm}$ の不均一の数個の陰影あり。

胸水なし。他には大動脈石灰化を認めた。 既往歴。平成元年12月早期胃癌と診断され、 平成 2 年 3 月に胃切除術を施行。

現病歷

平成 4 年 4 月、腰痛出現。

同年7月、胸部異常陰影発見される（近医）。 ○病院にて左下葉の肺癌と診断される。呼吸 機能不良にて当院紹介される。

8 月 25 日、第一外科診察。

9月 3 日、入院（胸痛なし。息苦しさない。腰 痛なし。)

$E K G$ 、正常 
9月 14 日、閉塞性呼吸障害を合併する肺癌患者 の術前トレーニングを理学療法にて開始。 10月8日、術前トレーニング全行程終了。 10 月 12 手術施行。

10月16日、起立・歩行開始（息切れなし。胸 苦しさなし。)

III. 理学療法プログラムと経過

理学療法は自転車エルゴメーターを使用し た運動負荷試験および、運動療法を行った。 運動療法には毎回、身体の柔軟性改善を目的 としたストレッチングを5分行わせた。さら に、呼吸筋强化を目的とした PFLEXによる呼 吸抵抗訓練も合わせて行った。

使用機器、自転車エルゴメーターはミナト社 製 $232 \mathrm{c} モ ニ タ ー$ 機器、日本光電社製パルス オキシメーター。日本電気三栄製呼気ガス分 析装置 2 L 01。サイベックス社製サイベックス II。他に血圧も測定した。
運動負荷試験は、メトロノームにて50拍のテ ンポにて35Wattより漸増負荷し、症候限界性 にエンドポイントを求め、最高運動負荷時の 酸素掑取量を测定した。

1) プロトコール

翌日筋疲労を来さぬ負荷（回転抵抗）を求め、 1 週間毎に増加することができた。以下に示す。 1週目: 25 Watt $\times 50 R P M \times 10$ 分、インターバル 5 分、繰返し数は 4 回、これを1日2回実施。 患者の運動療法の受け入れ：良好であった。 というのも、対処行動を記すと、本患者は理 学療法士の指示を熱心に聞き、説明中は終始 アイコンタクトが取れた。また、出診時間に なると病棟の指示に関わらず、運動に必要な 準備を全てすませて、時間に正確に訓練を行 った。特に、疑問を質問するようなことはな かった。

2週目: 34 Watt $\times 50 R P M \times 10$ 分、インターバル 5 分、繰返し数は2回、これを1日2回実施。 患者の運動療法の受け入れ：第 1 週と同様で

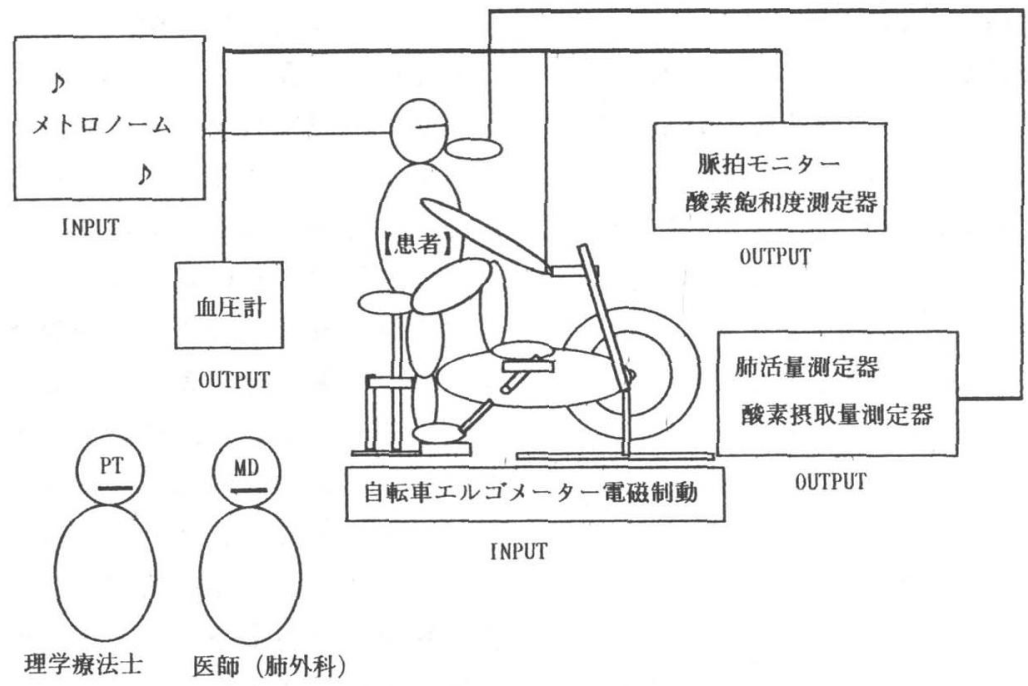

図運動療法の実施場面の模式 理学療法士と医師により、呼気ガス测定、脈拘を测定、電子メトロノーム、 自転車エルゴメーターにて運動強度設定を行っている。 
特に変化はなく、良好であった。

3 週目: 44 Watt $\times 50 R P M \times 10$ 分、インターバル 5 分、繰返し数は 2 回、これを 1 日 2 回実施。

患者の運動療法の受け入れ：第二週同様良好 であった。

4週目: 54 Watt $\times 50$ RPM $\times 10$ 分、インターバル 5 分、繰返し数は 2 回、これを 1 日 2 回実施。

患者の運動療法の受け入れ：ここまで経過し た様子と同じであった。

運動量は、約 $80 \mathrm{kcal} /$ 日としたが、4週目以降 $100 \mathrm{kcal} /$ 日とした。

呼気抵抗訓練はPFLEXを用いた。これは吸 気時に可変固定式に空気の流入に抵抗を与え、 呼吸筋負荷を狙う訓練機器であり、抵抗は 1 から6までまでの6段階に調節する器具である。

(6が最大抵抗) 2秒間の深呼吸を1日10-15分 $\times 2$ 回可能となると次段階に移行させた。

\section{2) 成績}

プログラム開始時（1週目）

定常状態平均心拍数 98 拍、Mets2.9、最高運動 時酸素提取量 $497 \mathrm{~m} 1 /$ 分

プログラム終了時（4週目）

定常状態平均心拍数 110 拍、Mets5.2、最高運 動時酸素摂取量 $891 \mathrm{~m} 1 /$ 分（開始時比 $76 \%$ 増） 下肢筋力は、開始時、大腿四頭筋 $48 \mathrm{ftbd}\left(60^{\circ}\right.$ /秒）、滕屈筋 $33 \mathrm{ftbd}\left(60^{\circ} /\right.$ 秒 $)$ が、終了時、 大腿四頭筋 $51 \mathrm{ftbd}\left(60^{\circ} /\right.$ 秒 $) 、$ 滕屈筋 $33 \mathrm{ftbd}$ (60 /秒) となった。 呼吸筋力はPFLEX值が開始時 2 より、終了時 6 になった。

\section{IV. 考 察}

我々がまず危惧した、運動療法の受け入れ は、医師によるインフォームドコンセントが えられ、終始、訓練態度には真剣さを感じる ことが出来た。この認識に基づいたであろう 運動療法と呼吸訓練に取り組む態度は病気に
打ち勝とうとする対処行動の要因として大き い効果があったと考えられる。訓練場面では、 ほぼ、毎回、医師と理学療法士が監視したこ とも患者から信頼とリラックスを得て、これ らのコンプライアンス向上に役立ったと思わ れた。

運動学的には、運動療法の筫と量に関して、 このプロトコールがより運動生理的に適切な 条件であったと思われるが、その理由の一つ が、療法士がより客観的な筋力測定值に基づ いた負荷を利用した強度設定を意図し実行し たことが、計画した運動量を全て患者に消化 させえた最大の要因であろう。

しかしながら、一臨床活動での取組である 本ケースからは意図的な介入研究と異なり、 特定の改善因子を選別することは困難である。

本結果は呼吸機能の改善因子と循環器機能 のそれとが混合したものである理由による。 現時点で、これらの意思決定条件に関わる関 連報告をみると、三好らは、実際的に肺切除 術後の肺癌患者では、かなり重篤なケースで 呼吸機能の管理に重点がおかれ、予後の良好 なケースでは循環器系機能の管理を重点的に 行っているようである1)-3。

我々は、運動負荷試験の適応となる患者に ついては、㡒環器機能の向上による酸素運搬 能力の向上を指向したプログラムを用意する ことが有効である印象を持っている。

本症例は負荷試験の際、安静時で呼吸困難 を示さず、漸増運動負荷時のある時点であき らかに標準に比して、それが露呈されるケー スであったが、病的な運動生理学的条件の記 述という点からみれば、臨床診断学への応用 として、このような症状が、これらのプログ ラムを適応する基準になる可能性がある。

運動療法の技術開発からみれば、さらに短 期間のものや、患者の負担の少ない安全なプ ロトコール開発の余地があると思われる。 


\section{V. 結 論}

術後合併症の発生が危惧された、本肺癌患 者の術前における、呼吸訓練及び運動療法は 最高運動時酸素摂取量を増大し、呼吸機能の 改善をもたらせた。

今後、改善に関わる要素の検討のほか、個 体差の影響、最適な強度設定技術の開発を目 的とした負荷プロトコール作りが求められよ う。

\section{VI. 参考文 献}

1) Miyoshi S Nakahara K Ohno K Monden $Y$ \& Kawashima Y: Exercise tolerance test in lung cancer patients: the relationship between.exercise capacity and post thoracotomy hospital mortality. Ann Thorac Surg B Nov;44(5):487-90.
1987.

2) Miyoshi S Nakahara K Monden Y \& Kawashima Y: Effect of lung resection on blood lactate threshold in lung cancer patients. Eur J Appl Physiol: $57(4)$ : $388-93.1988$.

3) Nakahara K Ohno $\mathrm{K}$ Hashimoto $\mathrm{J}$ Miyoshi S Maeda H Matsumura A Mizuta T Akashi A Nakagawa K \& Kawashima Y:Prediction of post operative respiratory failure in patients undergoing lung resection for lung cancer.Ann-Thorac-Surg. Nov; $46(5)$ : 549-52. 1988.

4) Nakagawa K Nakahara K Miyoshi S \& Kawashima $\mathrm{Y}: 0 \mathrm{xygen}$ transport during incremental exercise load as a predictor of operative risk in lung cancer patients. Chest. May; 101(5): 1369-75. 1992. 